Furthermore, in the experiments with rats, Vasopressin effect via TSH upon thyroid was determined by the increase of the following thyroid items : weight of thyroid, uptake of $I^{131}$, PBI $^{131}$ convertion ratio, $\mathrm{T} / \mathrm{S} \mathrm{I}^{131}$ ratio, thyroid index ; corresponding experiments were carried out with oxytocin for the purpose of comparison. The result are summarized as follows:

(1) Vasopressin, subcutaneously injected, gives rise to the acceleration of the pituitary thyroid activity in man, dog and rat.

This action of vasopressin in observed as

1) Elevation of plasma TSH level directly following the injection of vasopressin and

2) acceleration of thyroid activity. Oxytocin produces the same kind of enhancement of pituitary thyroid activity but in a for milder form (Fig. 1, 4, 6, 7, 8, 12).

(2) Vasopressin injection in subjects with various endocrine diseases, produces abnormal plasma TSH response as compared with the results of vasopressin test in normal subjects. Those cases with abnormally low anterior pituitary activity or pituitary destruction failed to respond upon vasopressin with increase of plasma TSH-level. Thus a fairly distinct functional test of anterior pituitary lobe could be developed with direct measurement of plasma TSH-level.

(3) Resection of the pituitary in rats abolishes the thyroid response upon vosopressin injection. Stalk section combined with celophanisation of the resected stalk brings about the lowering of plasma TSH. Vasopressin injection in the dogs with stalk section, produces a fairly distinct increase of plasma TSH-level.

These facts point out the plausible effect of .vasopressin upon pituitary-thyroid system, but this effect is brought about humorally and always first via anterior pituitary lobe.

(4) Medicaments such as reserpine, chlorpromazine and phenobarbital, which are believed to act upon hypothalamus, were given to the animals and the vasopressin effect upon plasma TSH-level was examined.

Only phenobarbital was able to suppress the increase of plasma TSH-level which normally follows the injection of vasopressin. The other two drugs showed no effect upon plasma-TSH response upon vasopressin.

\title{
Studies on the Insulin-like Activity and Glucagon-like Activity of Blood in Diabetic Subjects.
}

Some consideration on the regulation of hormonal secretion of the pancreas.

\section{Akira MATSUOKA, Hiroshi UOKAWA, Akira SAKAI, Atsuo ISHIHARA}

\author{
Department of Internal Medicine, Division II, Kobe Mcdical College, Kobc, Japan.
}

(Director : Prof. Shozo TSUJI, M.D.)

The authors have studied the behavior of insulin-like activity and glucagon-like activity of blood in comparison to blood sugar level of normal and diabetic subjects.

Venous blood was drawn from V. pancreatico-duodenale sup., V. portae, V. hepatica and V. femoralis and their blood sugar level, insulin-like activity and glucagon-like activity were examined

Vol. 37 No. 4 
312

simultaneously. The insulin-like activity was determined with the rat diaphragm method after Shimazu* and the glucagon-like activity was determined with the liver slice method after Shinko**.

Blood sugar was estimated with Hagedorn-Jensen's method. For the experiments, dogs of 7-8 kgm. body weight were used.

The results of observations are summarized as follows :

1) Insulin-like activity of fasting plasma drawn from diabetics, who had not received insulin treatment showed a low level as compared with normal subjects, whereas that of diabetics under treatment with long acting insulin preparations showed elevated value in comparison to normal level.

Glucagon-like activity of venous blood showed no conspicuous difference both on normal subjects and diabetics.

2) There was apparently an alternating relationship between insulin-like activity of blood and fasting blood sugar level in normal subjects and that group of diabetics, who had not received insulin treatment, i.e., the lower the fasting blood sugar level the higher the insulin-like activity of blood and conversely the higher fasting blood sugar level the lower insulin-like activity of blood.

3) In animal experiments, insulin-like activity and glucagon-like activity of blood drawn from V. pancreatico-duodenale sup. showed a slightly higher level as compared to the blood drawn from other venous sites, but insulin-like activity of venous blood drawn from other sites showed no conspicuous difference to each other.

Glucagon-like activity revealed a conspicuaus decrease after its passage through the liver parenchyma, i.e., ratio of glucagon-like activity of portal vein blood to that of hepatic vein blood represented $5.7: 1$.

This phenomenon seemed to elucidate the mechanism of glucagon effect and its break down in the liver.

* Published in the Japanese Journal of Gastro-Enterology, 57, 827, 1960.

** Addressed in the first Asia and Oceania Regional Congress of Endocrinology in 1959.

\section{Electron Microscopic Studies on the Endometrium of the Human Female}

\section{Isamu SAWARAGI}

Department of Obstetrics and Gynecology, Faculty of Medicine, Kyoto University

(Director : Professor Dr. Ryukichi Mibayashi)

The endometrium of the human sexually mature female reveals the regular menstrual cycle, namely, proliferative, secretory and bleeding phases. The phase to which the endometrial cell belongs can easily be differentiated. On this basis, the author aimed his investigation on the relation between the electron-microscopic ultra fine structure of cells and their functions.

The fresh endometrium was immediately fixed for 1 to 2 hours in a cold room, with $1 \%$ solution of osmic acid adjusted to $\mathrm{pH} 7.4$ by $1 / 100 \mathrm{M}$ of phosphate buffer and also brought to isotonic by $0.25 \mathrm{M}$ of sucrose. After being washed with distilled water several times, it was dehydrated by 


\title{
糖尿病患者の血中インンュリン相当值及び 血中グルカゴン相当值に就いて
}

\section{（附） 膵内分泌調節に就いての知見補遺}

\author{
神戸医科大学第二内科教室（指導 辻 昇三教授） \\ 松岡瑛, 魚川寛 \\ 酒 井瑛, 石 原 淳 生
}

（昭和35年10月29日受付）

緒言

糖尿病の病驡生理的研究としては膵内分泌機構の解明が，最も重要な研究課題の一つであるが，膡藏から 分泌される両種のホルモン即ちインシュリン及びグルカゴンの血中値の定量は, 幾多の研究に拘らず長い間 不可能であつた。

然し近年に至つて in vitro で組織切片を使用する Bioassay 法が確立され，漸く膆内分泌機構の変動を 追求する事が出来る様になつた。

我々の教室でも血中インシュリン值の測定には白鼠横隔膜法を, 血中グルカゴン值の測定には肝切片を利 用した Bioassay を考按し，乙れを多くの動物及び臨床実験に応用し新しい知見を得ている.

本篇は糖尿病の病態生理を解明する目的で始めた研究の一端で, 特に血液中の膵ホルモン濃度を測定し, これらホルモンの分泌乃至代謝機構を知らうとしたものである. 以下正常人と糖尿病者とのこれらホルモン 量の比較, 血糖俌との相関, 並びに正常犬に就いて同時採血に上る体内各部の血中ホルモン量の比較につい て述べ，2，3の検討を行つた結果に就いて報告する.

\section{実 験 方 法}

早朝空腹時に健康人及び糖尿病患者の肘静脈より採血を行い，血中インジュリン相当值（以下血中「イ」 相当值と略す）・グルカゴン相当值（以下血中「グ」相当値と略す）並びに血糖值を夫々測定した。

動物実験では体重 7 $8 \mathrm{kgm}$. の雌雄成犬を用い，食餌投与後12〜20時間絶食させた後実験に使用した. ペントバルビタール・ナトリウム（ミンタール, 田辺製薬製）麻䣲施行後, 比校的侵襲の少い栐江注意しつ つ上膵十二指腸静脈・門脈・肝静脈及び股動脈より可及的同時に採血し, 血中「イ」相当值・「グ」相当值 及び血糖值を夫々测定した。

血中インシュリン測定法には島津の白鼠横隔膜 4 分法 ${ }^{1)}$ を, 血中グルカゴン測定法は新光の白睩肝切片法2) を用い，血裾は Hagedorn-Jensen の方法により測定した。

\section{観 察 結 果}

正常人及び糖尿病患者の早朝空腹時血中「イ」相当値は図 1 の通り, 健康者群 17 例の平均は $13.95 \pm$ S.E. $5.16 \times 10^{-4} \mathrm{U} / \mathrm{cc}$ で, 軽症糖㽷病群 12 例 の平均は $11.96 \pm$ S.E.5.43 $\times 10^{-4} \mathrm{U} / \mathrm{cc}$ ，中等症糖尿病群 11 例平均は $4.30 \pm$ S.E.1. $38 \times 10^{-4} \mathrm{U} / \mathrm{cc}$, 重症糖尿病群10例平均值は7.75 \pm S.E.4.00 $\times 10^{-4} \mathrm{U} / \mathrm{cc}$ を示した. 長期作用持続 性インシュリンにて治療中の症例では, 48時間前より使用インシュリンを単純インシュリンに変更し, 最終 注射後約13時間以後の早朝空腹時血中「イ」相当値を測定したが, その平均值は $20.13 \pm$ S.E. $.5 .47 \times 10^{-4} \mathrm{U} / \mathrm{cc}$ 
第 1 図 正常人及び桾尿病者の血中インシュリン及びグルカゴン相当值
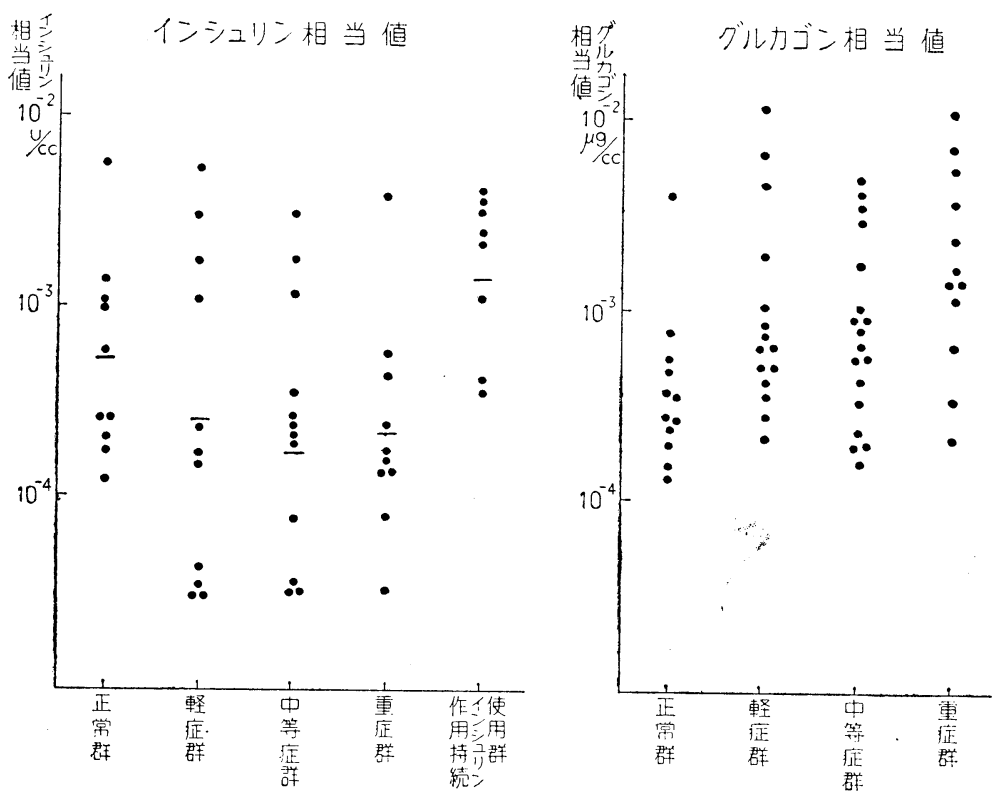

で他の健康者群・糖尿病者群より高值を示した。

正常人及び糖尿病患者の早朝空腹時血中「グ」相当值は図 1 の如く，正常人・軽症・中等症・重症群の間 には有意の差はみとめられず，略々同値を示

\section{していた。}

次に健康者群並びにインシュリン未使用糖 尿病者群の早朝空腹時に於ける血糖值と「イ」 相当值との関係をみると, 図 2 の如く血糖值 の低いもの程血中「イ」相当值の高いものが 多く, 丁度早朝空腹時血糖值の低い Group 中にみられた最高血中「イ」相当值と, 早朝空 腹時血糖值の高い症例が示す血中「イ」相当 值の二点を結んだ線と，血糖值及び血中「イ」 相当值を示す縦横の軸線とで囲まれた三角形 内に略々均等に散在している。

次に成犬の身体各部位における平均血糖值 は表 1 亿示す通り, 上膵十二指腸静脈血 98.4 $\mathrm{mg} / \mathrm{dl}$, 門脈血 $94.4 \mathrm{mg} / \mathrm{dl}$, 肝静脈血 100.6 $\mathrm{mg} / \mathrm{dl}$, 股動脈血 $97 \mathrm{mg} / \mathrm{dl}$ で肝静脈血糖值は 微量乍ら高值を示している. 血中「イ」相当 值は上膵十二指腸 静脈血 $1.14 \times 10^{-3} \mathrm{U} / \mathrm{cc}$. 門脈血 $8.513 \times 10^{-4} \mathrm{U} / \mathrm{cc} \cdot$ 肝静脈血 $9.715 \times$ $10^{-4} \mathrm{U} / \mathrm{cc}$ ・股動脈血 $9.45 \times 10^{-4} \mathrm{U} / \mathrm{cc}$ で上膵 十二指腸静脈血中の「イ」相当值は高值を示
第 2 図 正常者並びにインシュリン未使用糖 尿病患者の血糖值と血中インシュり ン相当值との相関

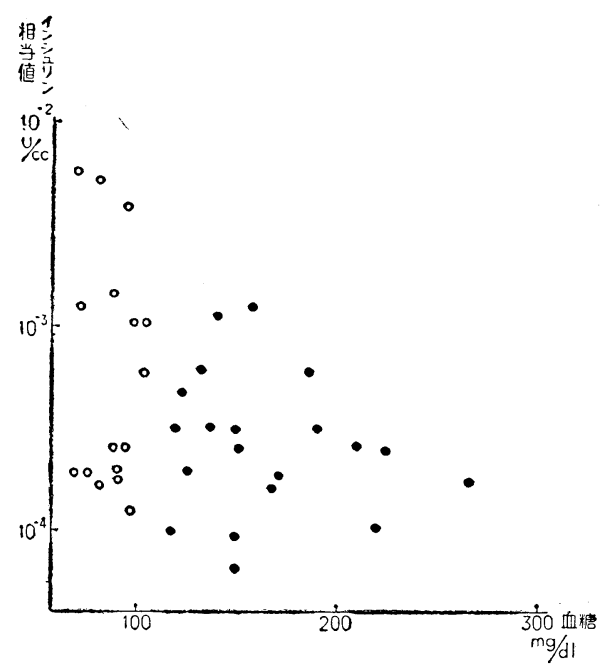

○正常者

○インシュリン未使用糖尿病患者 
第 1 表 同時採血による正常犬上膵十二指腸静脈, 門脈, 肝静脈, 股動脈血中のインシュリン 及びグルカゴン相当值の比較

\begin{tabular}{|c|c|c|c|c|c|}
\hline No. & & $\begin{array}{l}\text { 上臎十二指 } \\
\text { 腸 静 脈 }\end{array}$ & 門 & 肝＼cjkstart静 & 股 \\
\hline 1 & $\begin{array}{c}\text { 血 } \quad \text { 糖 } \mathrm{mg} / \mathrm{dl} \\
\text { インシュリン相当值 } \mathrm{u} / \mathrm{cc} \\
\text { グルカゴン相当值 } \mu \mathrm{g} / \mathrm{cc}\end{array}$ & $\begin{array}{c}102 \\
3.04 \times 10^{-4} \\
4.0 \times 10^{-3}\end{array}$ & $\begin{array}{c}99 \\
2.62 \times 10^{-4} \\
1.2 \times 10^{-3}\end{array}$ & $\begin{array}{c}106 \\
1.38 \times 10^{-4} \\
8.25 \times 10^{-4}\end{array}$ & $\begin{array}{c}104 \\
7.54 \times 10^{-4} \\
7.6 \times 10^{-4}\end{array}$ \\
\hline 2 & $\begin{array}{c}\text { 血 } \quad \text { 糖mg } / \mathrm{dl} \\
\text { インシュリン相当值 } \mathrm{u} / \mathrm{cc} \\
\text { グルカゴン相当值 } \mu \mathrm{g} / \mathrm{cc}\end{array}$ & $\begin{array}{l}\quad 98 \\
4.26 \times 10^{-3} \\
1.2 \times 10^{-3}\end{array}$ & $\begin{array}{l}\quad 94 \\
3.77 \times 10^{-3} \\
4.5 \times 10^{-4}\end{array}$ & $\begin{array}{l}\quad 109 \\
3.89 \times 10^{-3} \\
1.0 \times 10^{-4}\end{array}$ & $\begin{array}{c}\quad 106 \\
3.49 \times 10^{-3} \\
7.1 \times 10^{-4}\end{array}$ \\
\hline 3 & 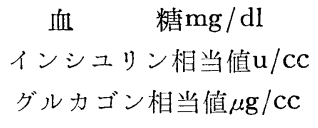 & $\begin{array}{l}\quad 108 \\
7.45 \times 10^{-4} \\
1.5 \times 10^{-2}\end{array}$ & $\begin{array}{c}101 \\
9.34 \times 10^{-5} \\
1.80 \times 10^{-2}\end{array}$ & $\begin{array}{c}103 \\
2.52 \times 10^{-4} \\
1.6 \times 10^{-3}\end{array}$ & $\begin{array}{c}\quad 95 \\
1.75 \times 10^{-4} \\
1.1 \times 10^{-3}\end{array}$ \\
\hline 4 & 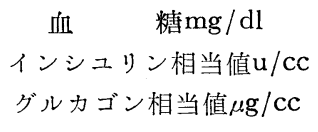 & $\begin{array}{l}\quad 107 \\
6.25 \times 10^{-5} \\
8.6 \times 10^{-4}\end{array}$ & $\begin{array}{c}104 \\
4.6 \times 10^{-5} \\
1.0 \times 10^{-3}\end{array}$ & $\begin{array}{l}\quad 104 \\
6.18 \times 10^{-5} \\
8.1 \times 10^{-4}\end{array}$ & $\begin{array}{c}92 \\
5.80 \times 10^{-5} \\
4.0 \times 10^{-4}\end{array}$ \\
\hline 5 & 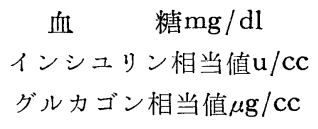 & $\begin{array}{c}77 \\
3.39 \times 10^{-4} \\
5.19 \times 10^{-3}\end{array}$ & $\begin{array}{l}\quad 74 \\
8.51 \times 10^{-5} \\
3.7 \times 10^{-3}\end{array}$ & $\begin{array}{l}\quad 81 \\
5.16 \times 10^{-4} \\
9.2 \times 10^{-4}\end{array}$ & $\begin{array}{c}\quad 88 \\
2.48 \times 10^{-4} \\
7.0 \times 10^{-4}\end{array}$ \\
\hline $\begin{array}{l}\text { 平 } \\
\text { 均 }\end{array}$ & $\begin{array}{c}\text { 血 } \quad \text { 糖 } \mathrm{mg} / \mathrm{dl} \\
\text { インシュリン相当值 } \mathrm{u} / \mathrm{cc} \\
\text { グルカゴン相当值 } \mu \mathrm{g} / \mathrm{cc}\end{array}$ & $\begin{array}{c}98.4 \\
1.14 \times 10^{-3} \\
5.25 \times 10^{-3}\end{array}$ & $\begin{array}{l}\quad 94.4 \\
8.513 \times 10^{-4} \\
4.87 \times 10^{-3}\end{array}$ & $\begin{array}{c}100.6 \\
9.715 \times 10^{-4} \\
8.51 \times 10^{-4}\end{array}$ & $\begin{array}{c}97 \\
9.45 \times 10^{-4} \\
7.34 \times 10^{-4}\end{array}$ \\
\hline
\end{tabular}

している．血中「グ」相当佔については，上膵十二指腸静脈血 $5.25 \times 10^{-3} \mu \mathrm{g} / \mathrm{cc} \cdot$ 門脈血 $4.87 \times 10^{-3} \mu \mathrm{g} / \mathrm{cc}$ ・ 肝静脈血 $8.51 \times 10^{-4} \mu \mathrm{g} / \mathrm{cc} ・$ 股動脈血 $7.34 \times 10^{-4} \mu \mathrm{g} / \mathrm{cc}$ であつた。. 血中「グ」相当值は肝通過前後に汱ける比 が 5.7 対 1 と通過前が高値を示し，上膵十二指腸静脈血と門脈血との間に，又肝静脈血と股動脈血 の血中 「グ」相当値の間には，夫々有意の差がみられなかつた。

\section{考按}

糖尿病を組織学的に検索しようとした Warren ${ }^{33}$ ，Herxheimer ${ }^{4}$ 等は，膵う氏島に何ら異常所見を認めてな (糖尿病症例を $20 \sim 27 \%$ 亿発見し，又 Bell ${ }^{5)} も \beta$ 顆粒と糖尿病の軽重の間に関連を認めないと述へてている。

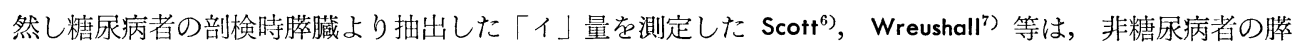
抽出「イ」量より少いと報告している．我国に於ても小坂・八川8き同様の結果を得ている.

しかし色々の機能的背景を有する剖検時の荟藏「イ」量の低下を直ちに糖尿病の一次的原因であると断定 してしまう事は危険な事であうう。

最近 Groen ${ }^{9)}$ Bornstein ${ }^{10) 11)}$ Vallance-Owen ${ }^{12)}$ らはそれぞれ血中「イ」量を測定し，健康者と糖尿病者と を比較し，いずれも非肥満型糖尿病及び糖尿病昏杹では正常者より低值を示し，治療中のものはかえつて高 値を示しているとしている.

我々は白鼠横隔膜法 ${ }^{11}$ にる血中「イ」值測定では，正常者群と糖尿病者群を軽・中等・重症及び治療中 亿分類し検討を加えた。糖尿病の分類は二重負荷試験成績に㤻て, 第二回糖負荷後の最高血糖值か $250 \mathrm{mg} / \mathrm{dl}$ 以下を軽症群，中等症は最高血糖値が $250 \sim 400 \mathrm{mg} / \mathrm{dl}$ にあるものを，重症群は最高血糖 $400 \mathrm{mg} / \mathrm{dl}$ 以上のも 
のとした.

糖尿病者血中「イ」相当值は正常者に比し低値を示している，而して正常者优い軽症者では，血中「イ」 相当值も高く正常者に近い成績を示す，中等症と重症例ではいづれも血中「イ」相当值は低いが，中等症と 重症の間では平均值としては重症の方が高く，病状の程度と血中「イ」相当値の間の逆相関関係を直接には 認め難い成績を示している，又治療群が血中「イ」相当値の高值を示している事は Groen ${ }^{9}$ V Vallance-Owen 12)等も報告する所であるが，我々の成績でもてれと一致する成績を得た。

血糖值と血中「イ」相当值との関係については，Vallance-Owen ${ }^{12)}$ は明らかな相関関係を得たとしてい る. 我々の実験では血糖值の低い症例では血中「イ」相当值はかなりの巾の高低を有し,Vallance-Owen ${ }^{12}$ の報告にみられる相関は認め難かつた。インシュリン未使用の糖尿病者の血糖と血中「イ」相当值の相関に ついての報告は未だ行われていないが, 我々の実験成績では逆相関的関係にあり, 早朝空腹時血糖值の高い ものほど血中「イ」相当值は低く, 糖尿病の軽重と血中「イ」相当値の高低の間には或る程度の相関が存在 するととを示している．てれらの事項に就いては教室島津の報告1)と一部一致する所である.

次に各部位に於ける血中「イ」及び「グ」相当值の問題であるが，近年膵内分泌 Hormone の生体内に於 ける作用機序並びに代謝の様相を解明する一助として，放射能を附与した Insulin.Glucagon を生体内に静 注し, 各藏器及び組織への分布とその分解の状況を研究する事が可能となつてきた。

静注された Insulin $I^{131}$ は腎・次いで肝・笳に高率に集中し ${ }^{13)}$ ，又一方 Glucagon $I^{131}$ は腎・血漿・肝 に多量に集まる事が知られ ${ }^{14)}$ ，而も肝が腎と共にインシュリン・グルカゴン両ホルモンの主たる代謝藏器で ある事は種々報告されている ${ }^{15)} 24$.

我々の実験は主として空腹時・静的状態に於ける肝通過前後の膵内分泌ホルモンの消長について観察を行 つたもので，先に述べた所の体外より負荷されたてれら両ホルモンの各臟器に於ける消長に関する実験成績 と直接比較は難しいが，我々の測定成績に依ると，一般に上膵十二指腸静脈血中では「イ」值・「グ」值共 に軽度乍ら高值を示し，殊に上膵十二指腸静脈一門脈血中「グ」相当值が他の 部位より採血した血中「グ」 相当值より高值をとる点から考光て, 従来から報告されているグルカゴンの産生部位が主として膵ラ氏島の $\boldsymbol{\alpha}$ 細胞ではないかと云われている河 28)説を支持する成績としてよい.

更に膵静脈-門脈血の「グ」相当値が肝通過後の肝静脈一股動脈血中「グ」相当值より高值を有し，特に門 脈血と肝静脈血中「グ」相当值の比が 5.7 対 1 と前者が高い．乙れは我々の測定するグルカゴンが，肝で分 解されると云う先に述べた報告と一致する成績である。

我々の測定した血中「イ」值に就いては各部位に於て有意の差を認めなかつた。葛谷 ${ }^{29}$ ( は膡十二指腸静 脈・門脈・肝静脈の順序にインシュリン効果が減少し, 特に門脈と肝静脈の血清インシュリン効果の差が非 常に大きく，インシュリンは肝を通過するに当り強力に非活性化されるものと諒解されると述べており，又 先述した通りインシュリンの分解が主として朋・警に於て行われるとされているが，我々の測定では必ずし もこれに一致しなかつた。

てれは肝（腎）に於けるインシュリンの非活性化は，特に我々の測定した空腹時・静的状態の条件下では 微少であつて我々の測定法にてはかから程度のものと考えたい.

インシュリンとグルカゴンの両ホルモンの糖代謝〔に於ける作用について Bürger ${ }^{30)}$, Erlick ${ }^{31322)}$, Rossi ${ }^{33)}$, 吉岡 ${ }^{34)}$, 阿部 ${ }^{35)}$ 等は協調作用を主張しているが, 教室の魚川 ${ }^{36)}$ の糖負荷時の成績, 及び松岡 ${ }^{37}$ の脂肪・アミ ノ酸負荷時の成績に於ても, 或る面ではこの両ホルモンの協調作用のあるととを認めた。 ての際両ホルモン の分泌機構としては，インシュリン・グルカゴンを要求する組織の代謝状態によつて通常先づグルカゴンが 分泌され，インシュリンへの作用の場を提供すると共に，一旦消費されて減少したインシュリンの追加分泌 が惹起される点を㨁調したのであるが，今回の実験のような静的状態時に彾てもインシュリン・グルカゴン 両モルモンの微妙な調節は常時行われていると考えてよい上うである. てれについては Anderson ${ }^{38339)}$ が短 時間頻回採血による実験の絬果, 生理的条件下でも血糖は絶えず動摇しながら消長していると云う成績を出 している点からも充分に予測されるもので，従つて我々の測定した成績は静的条件のもとではあるが，微細 
392 糖尿病患者の血中インシュリン相当值及び血中グルカゴン相当值に就いて（松岡，魚川，酒井，石原）

な両ホルモンの分泌・調節の一瞬時をみたもので，インシュリン值に就ての葛谷 ${ }^{29}$ の成績との相違もこのよ うに理解すれば予想外の出来事ではないであろう.

結 論

1）インシュリン未使用糖尿病者群早朝空腹時血中「イ」相当值は正常群の夫れより低值で, 作用持続性 インシュリン使用糖尿病者群は正常群より高值を示した.

「グ」相当值に就いては，正常群・糖尿病者群の間に有意の差が認められず，略々同值を示していた.

2) 健康者及びィンシュリン未使用糖尿病者群の早朝空腹時に於ける血糖值と血中「イ」相当值との間の 相関をみると, 血糖値の低いもの程血中「イ」相当值は高值を, 血糖值の高いもの程血中「イ」相当值は低 值を示し，乙の両者の間に逆相関的関係があるものと考えられた.

3）空腹時正常犬の上膵十二指腸静脈・門脈・肝静脈・股動脈血中「イ」「グ」相当值及る゙血糖值を測定 し，一般に上膵十二指腸静脈血中の「イ」相当值及び「グ」相当值に就いては軽度乍ら高值を認めたが，其 の他の血糖值及び血中「イ」相当值に就いては各部位共みるべき差を認めなかつた. 但し血中「グ」相当值 は肝通過前後に於ける比が5.7対 1 と通過前が高值を示した.

（尚本稿の要旨は昭和33年第31回日本内分泌学会及び昭和33年第 6 回日本内分泌学会西日本地方会に於て 発表したものである。）

稿を終るに当り，終始御懇切な御指導を賜つた恩師辻昇三教授に厚く感謝致します.

文献

1）島津幸作：消化機病誌，57:827，1960. $\quad$ 2) 新光 毅 : Addressed in the first Asia and Oceania Regional Congress of Endocrinology in $1959 . \quad 3)$ Waren, S. \& Le Compte, P.M.: The pathology of diabetes mellitus, Lea \& Febiger, Philadelphia, $1952 . \quad$ 4) Herxheimer, G.: Verh. ges. Verdgskrht, $11: 112,1933 . \quad$ 5) Bell, E.T. : Experimental diabetes mellitus, Sprengfield, C.G. Thomas. 1948. 6) Scott, D.A. \& Fisher, A.M. : J. Glin. Invest., $17: 725,1938 . \quad 7)$ Wreushall, G.A. \& Ritschie, R.C. : Canad. M.A.J., $74: 968,1956 . \quad 3)$ 小坂樹徳, 八川宗一, 水野美淳 : 最新医 学, $8: 714,1953$ 9) Groen, C.E. et al. : J. Glin. Invest., $31: 110,1952 . \quad$ 10) Bornstein, J. \& Lawrence, R.D. : Brit. Med. J., I : 732, $1951 . \quad 11)$ Bornstein, J. \& Lawrence, R.D. : Brit. Med J., II : 1541, $1951 . \quad$ 12) Vallance-Owen, J. et al. : Lancet, II : 983, $1954 . \quad$ 13) Elgee, N.J. et al. : J. Clin. Invest., $33: 1252,1954 . \quad 14)$ Cox, R.W. et al. : Endocrinol., $60: 277,1957$. 15) Elgee, N.J. et al. : Proc. Soc. Exp. Biol. \& Med., $87: 178,1954 . \quad 16)$ Elgee, N.J. et al. : Proc. Soc. Exp. Biol. \& Med., $87: 352,1954 . \quad 17)$ Lehmann, H. et al. : J. Physiol., $94: 15,1938$. 18) Mirsky, I.A: et al. : Arch. Biochem., $20: 1,1949 . \quad$ 19) Narahara, H.T. et al. : J. Biol. Chem., $217: 675,1955 . \quad 20)$ Stadie, W.C. et al. : J. Biol. Chem., $200: 745,1953 . \quad 21)$ Tomizawa, H.H. et al. : J. Biol. Chem., $214: 285,1955 . \quad 22)$ Weisberg, H.F. et al. : J. Physiol., $158: 332$, 1949. 23) Narahara, H.T. et al. : Endocrinol., $60: 285,1957 . \quad 24)$ Kenny, A.J. : Am. J. Physiol., $186: 419,1956 . \quad 25)$ Audy, G. et al. : Biochem. J., $52: 77,1952 . \quad 26)$ De Duve, C. : Lancet, $2: 99,1953 . \quad 27)$ Fodden, J.H. et al. : Endocrinol., $54: 303,1954$. Sutherland, E.W. et al. : J. Biol. Chem., $175: 663,1948 . \quad 29)$ 葛谷覚元 : 日消化機病誌, $55: 178$, 1958. 30) Bürger, H. et al. : Z. ges. Exp. Med., $96: 375,1935 . \quad 31)$ Erlick, H. et al. : J. Clin. Invest., $34:$ 1830, $1955 . \quad 32)$ Erlick, H. et al. : J. Clin. Invest., $35: 757,1956$. Rossi, E. et al. : Schweiz. Med. Wschr., $87: 1009$, 1957. 34$)$ 吉岡 — : 内分泌, $3: 97,1956$.

35) 阿部正和他 : 内分泌, $3: 299,1956$.

38) Anderson, G.E. : Science, $119: 516,1954$.
36）魚川 寛 : 未発表. 37）松岡 瑛 : 未発表 39) Anderson, G.E. : Science, $122: 457,1955$. 